\title{
SABBATH RECONSIDERED: HUMAN DIGNITY AND THE FOURTH COMMANDMENT
}

\author{
L Juliana M Claassens \\ Old and New Testament \\ Stellenbosch University
}

\begin{abstract}
This paper will consider the meaning and significance of the Sabbath commandment through the lens of human dignity, considering how various communities in the biblical traditions wrestled with the question of how to remember the Sabbath and keep it holy. So the Sabbath commandment will be read in terms of the dual commandment to work as well as to rest underlying this commandment, showing how the basic human right to work as well as to rest forms an important part of reading this commandment in terms of a human dignity framework. In particular, this paper will show that reading the Sabbath in terms of human dignity may offer theological resources to contemporary communities to resist the growing tendency of disrespecting or violating people's humanity when it comes to the central desire and need to work.
\end{abstract}

Key Words: Sabbath, Human Dignity, Ten Commandments, Old Testament Ethics

\section{Introduction}

Remember the sabbath day, and keep it holy.

Six days you shall labor and do all your work.

But the seventh day is a sabbath to the LORD your God; you shall not do any work-- you, your son or your daughter, your male or female slave, your livestock, or the alien resident in your towns.

For in six days the LORD made heaven and earth, the sea, and all that is in them, but rested the seventh day; therefore the LORD blessed the sabbath day and consecrated it.

(Exo 20:8-11NRS)

So reads the $4^{\text {th }}$ commandment of the Decalogue from Exod 20:8-11 (cf. also Deut 5:1215). From its widespread occurrence in both the Hebrew Bible, as well as in the New Testament, it is evident that this commandment was considered to be quite important for Israel's religious understanding. However, there has been much divergence as to what this Sabbath rest actually entails throughout the biblical traditions, as well as in various Jewish and Christian communities till this day. For example, one extreme example comes from a rather terrible story told in Num 15:32-36 of the man who was found gathering firewood on the Sabbath day. The story relates how the Israelites brought the man before the leaders Moses and Aaron and the whole congregation and how "they put him in custody, because it was not clear what should be done to him." Then the divine commandment comes echoing the law in Exod 31:12-17 that "the man shall be put to death; all the congregation shall stone him outside the camp" - a grave punishment indeed for violating the commandment 
to do no work on the Sabbath day and a sure sign of just how serious this commandment is taken by this particular community.

The fear inspired by this 'text of terror' - which incidentally is a sound illustration of the fact that one runs into all kinds of trouble if one were to take the biblical text literally to the letter of the law - may be behind the tendency to spell out in detail what is allowed and what not when it comes to observing the Sabbath as evident in the 39 melachot (categories of work - cf. the Hebrew word for work malacha) in the rabbinic tradition that prohibit among other, "Sowing, Plowing, Reaping, Sifting, Kneading, Baking, Spinning, Weaving, Building, Tearing something down, Extinguishing a fire, Kindling a fire, Writing two or more letters, Erasing two or more letters" (Mishna Shabbat 7:2). Or to a lesser extent in the endless do's and don'ts of our childhood and even further back - in our parents' generation swimming on Sunday was forbidden and so to was playing games, doing needlework, buying Sunday newspapers, etc, etc.

Today the observation of the Sabbath commandment has moved to the other extreme where Sunday has become a day just like any other day. Sundays are spent shopping, working, and playing around the clock raising serious questions about whether there is still any significance in this $4^{\text {th }}$ commandment for contemporary communities. More seriously though, the way the Sabbath has been filled in today's rat-race has become the space in which the dignity of people all too often is obscured or even violated.

Considered from a different angle, the Sabbath commandment actually offers great potential to make a meaningful contribution in the conversation on human dignity in the biblical traditions. It is significant that in the exilic period, the observation of the Sabbath gained in significance, when as Johanna Van Wijk-Bos points out, "it served as a mark of identity both for the community in exile and for the one left behind in Judah, with holy time replacing holy space as long as the temple lay in ruins." ${ }^{\text {Th }}$ This paper will consider whether an alternative understanding of the Sabbath may offer theological resources to contemporary communities to resist the growing tendency of disrespecting or violating people's humanity when it comes to the central desire and need to work, so becoming a new identification mark of a community that considers human dignity as not only important but foundational to our common life together.

Moreover, the $4^{\text {th }}$ commandment (in conjunction with the $5^{\text {th }}$ commandment regarding honouring one's parents) has been said to serve as a bridge commandment between the first and the third set of laws. According to Martin Buber, "[i]f the first parts deal with the God of the Community, and the second with time, the one-after-the-another of the Community, the third is devoted to space, the with-one-another of the Community in so far as it establishes relations between its members."2 The Sabbath thus functions as an important space in which we can reflect on our relationship with God and our relationship with others. It is in the right relationship with God that believers will cultivate right relationships with their neighbours.

However, as will be evident in the rest of this paper, what this right relationship with the neighbour comprises is open to discussion and even dispute. It seems as if the lack of specificity in the commandments and particularly the Sabbath commandment of what

\footnotetext{
Johanna van Wijk-Bos, Making Wise the Simple: The Torah in Christian Faith and Practice (Grand Rapids: Eerdmans, 2005), 54.

2 Martin Buber, Moses: The Revelation and the Covenant (New York: Harper, 1958), 133. Cf. also Van WijkBos, Making Wise the Simple, 160; Patrick Miller, The Ten Commandments (Interpretation; Louisville, KY: Westminster John Knox, 2009), 117.
} 
constitutes work and rest, gave the community the freedom to work out the details that would differ depending on the particularities of different times and occasions. ${ }^{3}$ In this paper we will see some examples of this ongoing quest to discern the meaning and significance of a commandment such as observing the Sabbath is seen in subsequent biblical traditions where we see evidence of communities wrestling with the question of how to remember the Sabbath and keep it holy.

\section{Sabbath Reconsidered}

Before turning to some thoughts on how the conversation on human dignity may enrich our understanding of the Sabbath commandment (and vice versa), the following two observations are important for the interpretation of the Sabbath commandment in a context of human dignity.

First, it is significant to see that already in the two versions of the Decalogue itself there are inherent multiplicity and/or ambiguity. When one compares the two versions, one finds different motivations for the commandment 'to remember' זָכוֹ (Exod 20:8) and 'to observe' שָָמור (Deut 5:12) the Sabbath. The Exodus 20 version links the Sabbath commandment to creation when drawing on an implicit reference to the Imago Dei (humans created in the image of God as stated in Gen 1:26-27): people are called to rest as God has rested. ${ }^{4}$ This commandment refers back to Gen 2:2-4 in which after God created humankind in God's image (Gen 1:27), God finishes his work on the $7^{\text {th }}$ day, blessing the Sabbath and declared it holy. From Exodus 20 it is thus clear that the commandment to observe the Sabbath is from the very beginning built into the structure of creation. ${ }^{5}$

Alternatively, the Deuteronomy version of the Sabbath commandment offers quite a different motivation for the commandment to rest that connects with Israel's own experience of suffering during the time that they lived as strangers in a strange land which saw them severely oppressed by those in power. We read in Deut 5:12-15:

Observe the sabbath day and keep it holy, as the Lord your God commanded you. Six days you shall labor and do all your work. But the seventh day is a sabbath to the LORD your God; you shall not do any work - you, or your son or your daughter, or your male or female slave, or your ox or your donkey, or any of your livestock, or the resident alien in your towns, so that your male and female slave may rest as well as you.Remember that you were a slave in the land of Egypt, and the Lord your God brought you out from there with a mighty hand and an outstretched arm; therefore the Lord your God commanded you to keep the sabbath day.

This memory of suffering thus serves as the basis for the commandment to allow your male and female slave to rest as well; the memory of God's liberation in one's own life is

\footnotetext{
Van Wijk-Bos points out that "the specific laws following the Decalogue in Exod 20:22-23:33 may be viewed as one way the Ten Words were given specific shape in the ancient faith community. At the same time, a certain indeterminacy allows for the list of Ten to find new specificity and articulation according to the requirements of different times and context," Making Wise the Simple, 162-163.

4 In Gen 2:3 it is said that God finished or ceased (Hebrew s aŏbat) his work. In Exod 20:11 the Hebrew word for 'rest' is used to describe God's activity on the $7^{\text {th }}$ day, so equating stopping work with resting, Miller, The Ten Commandments, 124-125.

5 Walter J Harrelson notes that the Sabbath ignores all normal rhythms of measuring time, thus not following the agricultural calendar, or the seasons or the movement of the sun, moon and stars, The Ten Commandments and Human Rights (Macon, GA: Mercer University Press, 1997), 68-69. Moreover, by including the Sabbath as the culmination of God's work, "the narrators include the entire world within the framework of sacred time," Van Wijk-Bos, Making Wise the Simple, 95.
} 
responsible for the call to effect release for others in one's service, albeit only for one day in a week. In this regard, one should note the biblical text does not shy away from acknowledging unjust structures that exist in society. ${ }^{6}$ The idea of one day of Sabbath rest for your slaves certainly does not alter the very institution of slavery that was so painful back then for many indentured servants, ${ }^{7}$ as well as for people finding themselves in a context such as the American South ${ }^{8}$ or closer to home in South Africa with indentured service continuing long after slavery was officially abolished. Moreover, viewed from a feminist sensitivity it is glaringly obvious that women (the wives of the male addressee) are not explicitly included in the commandment to rest.

In spite of these blind spots in the text, and amidst and probably because of these unfair institutional arrangements, one sees how the Sabbath serves as a reminder to challenge injustice and situations in which people's dignity is violated. In this regard, Abraham Heschel writes that the Sabbath is a gracious gift from God that offers us a glimpse of the world to come. On this day that comes around once a week, one sees an image of a world where rich and poor, slave and free, men and women all spend the day away from the work that so often create division among people from different socio-economic classes occupying them with one common task, i.e. to rest. ${ }^{9}$

Second, like many of the other commandments, the Sabbath commandment contains both a positive and a negative ruling. ${ }^{10}$ So Israel is both called to work and not to work. A prerequisite for resting on the Sabbath day implies that one is able to work in order to make a living or to fill six days of the week with some other meaningful activity. But without the deeply human need to rest, work becomes a cruel slave-master reminiscent of the slave labour Israel had to endure in Egypt. These two sides of the argument - the need to work, as well as the need to rest lead me to make a number of comments about the way in which the Sabbath commandment relates to the broader question with regard to human dignity.

\section{Human Dignity and Work}

Prior to the Sabbath commandment's decree of a weekly day to rest, the commandment asserts that people should work six days of a week, thus expressing the basic human right to work and to earn a living for oneself and for one's family. Walter Harrelson rightly points out that this commandment makes a theological point that 'meaningful and fulfilling work' is a divine expectation, challenging us to not merely accept the impossibly high

6 Miller, The Ten Commandments, 130. Also in texts like Exod 21:2-6, one finds a glaring disparity when female slaves are not set free on an equal basis similar to their male counterparts, or in Deut 15:2-3, the release of debt is only intended for one's fellow Israelite and not for the foreigners living amongst you.

7 Rainer Albertz describes the plight of a large percentage of Israel's population as follows: "All the groups were caught in the mill of the harsh ancient law of credit, which allowed the creditor to seize the property and the family of the debtor ... if they were unable to pay... The poorer strata of the population were driven into increasing poverty and had to hand over their children, i.e., their workforce, to their creditors as slaves; they had to give them the lion's share of the produce of their fields and their vineyards and themselves worked only as leaseholders or as slaves on their former property - that is, if they and their children were not driven out and sold into slavery abroad," A History of Israelite Religion in the Old Testament Period: Vol 2 From the Exile to the Maccabees (Louisville, KY: Westminster John Knox,1994), 495-496; Cf. also Van Wijk-Bos, Making Wise the Simple, 47.

8 Cf. Beverly Eileen Mitchell, Plantations and Death Camps: Religion, Ideology and Human Dignity (Minneapolis: Fortress, 2009), 1-38 for an exposition of the atrocities of slavery and the effect on human dignity.

9 Abraham Joshua Heschel, The Earth is the Lord's and The Sabbath (New York: Harper \& Row, 1962), 73-75; Miller, The Ten Commandments, 122; Van Wijk-Bos, Making Wise the Simple, 54.

10 Miller, The Ten Commandments, 117. 
unemployment rate that mars not only this country but that has spread like wildfire across the world's recent string of recessions. Harrelson writes that "the human community cannot accept situations in which people, young or not so young, seek employment in order to find fulfilment in work and also to earn their living but can find no work." 11 To be able to work can be linked to one's self worth and dignity, particularly as it relates to one's ability to fulfil your basic needs of housing, sustenance and clothing, as well as the ability to provide educational opportunities for oneself and for your children. ${ }^{12}$

Moreover, it is also a question of the quality and the degree to which this work contributes to a sense of wellbeing and gratification. Labour can become oppressive and meaningless - a notion expressed well in the classic example from the Greek mythology, Sisyphus, who as punishment from the gods was condemned for all eternity to push a stone up a hill only to have it roll down again. It is no wonder that Albert Camus uses the example of Sisyphus in a philosophical essay as a metaphor for workers in his day who spent their lives working at dead-end jobs in factories and offices. ${ }^{13}$

In our globalized world it seems that work has become increasingly fragmented and depersonalized; employees being able to expect little humaneness or loyalty from their employers. The Sabbath commandment thus serves as an imperative to counter the ugly face of capitalism's relentless surge for profit, as well as globalization that affects us all, but in particular exploits the poor and vulnerable in countries far away. ${ }^{14}$ The question underlying the Sabbath commandment is whether there are ways to humanize work by creating workplaces in which workers are treated as humans and not as dispensable pieces in a profit-making machine; where people are paid fair wages that show respect for their inherent desire to provide for their own, as well as for their families' basic needs. ${ }^{15}$

11 Harrelson, The Ten Commandments and Human Rights, 73.

12 Fraser Watts offers some important insights with regard to the language of 'the right to work.' He argues that most people would agree that work is important for people to survive on the one hand but also to actualize themselves in meaningful ways. He argues as follows: "The Christian tradition provides the resources to understand the value of work and why it is a human good... [However], [t]o think theologically about dignity as gift represents a very different approach from the discourse about rights to which dignity is often tied in contemporary thought... Seeing dignity as a gift carries tasks and obligations appropriate to good stewardship of the gift, whereas rights thinking carries no such obligation, 'Human Dignity: Concepts and Experiences,"” in God and Human Dignity (eds. R Kendall Soulen \& Linda Woodhead; Grand Rapids, MI: Eerdmans, 2006), 255-256.

13 Albert Camus, 'The Myth of Sisyphus,' in The Plague, The Fall, Exile and the Kingdom, and Selected Essays, (New York: Alfred A Knopf, 2004). Cf. Heschel's poignant statement that captures something of Camus' critique: "Labor without dignity is the cause of misery; rest without spirit the source of depravity," The Sabbath, 18. Cf. also Miller's argument regarding the two sides of work that is evident in two adjacent Psalms, i.e. Psalm 127 and 128. So in Psalm 128:1-2 work is celebrated as exhibiting positive possibilities, offering access to a meaningful existence and giving significance to life. However, as in Psalm 127 one finds a different picture regarding 'anxious toil' which Miller describes as follows: "Such hard driven, unrelenting labor has a kind of emptiness to it."As Miller rightly points out, what protects work from becoming like this is the Sabbath, The Ten Commandments, 121.

14 David Fields aptly describes the effects of globalization as follows: "This elite group moves money throughout the world at the touch of a computer keyboard - buying selling maximum reward... The economic future of a distant country can be enhanced or destroyed at the touch of a button, on the basis of a rumor, for the benefit of people who will never even visit it." "On (Re) Centering the Margins: A Euro-African Perspective on the Option for the Poor," Opting for the Margins: Postmodernity and Liberation in Christian Theology (ed. Joerg Rieger; Oxford: Oxford University Press, 2003), 50.

15 M Douglas Meeks asks the following probing questions regarding a Christian response to globalization: "If there is a kind of inevitability to globalization, especially because of the technologies of communication and transportation, Christian anthropology has to press the question whether globalization can be guided in ways that humanize. What view of the human being and what polity would this require?" "The Economy of Grace: Human Dignity in the Market System," in God and Human Dignity (eds. R Kendall Soulen \& Linda 
Two biblical texts from very different times and places offer us some contrasting examples of how the Sabbath has been filled in by their respective communities. In Neh 13:15-21, one finds an intriguing text that indicates that the commercialization of the Sabbath is nothing new. We read how people turned the Sabbath day into a market day, buying and selling goods:

In those days I saw in Judah people treading wine presses on the sabbath, and bringing in heaps of grain and loading them on donkeys; and also wine, grapes, figs, and all kinds of burdens, which they brought into Jerusalem on the sabbath day; and I warned them at that time against selling food. Tyrians also, who lived in the city, brought in fish and all kinds of merchandise and sold them on the sabbath to the people of Judah, and in Jerusalem. Then I remonstrated with the nobles of Judah and said to them, "What is this evil thing that you are doing, profaning the sabbath day? Did not your ancestors act in this way, and did not our God bring all this disaster on us and on this city? Yet you bring more wrath on Israel by profaning the sabbath." When it began to be dark at the gates of Jerusalem before the sabbath, I commanded that the doors should be shut and gave orders that they should not be opened until after the sabbath. And I set some of my servants over the gates, to prevent any burden from being brought in on the sabbath day. Then the merchants and sellers of all kinds of merchandise spent the night outside Jerusalem once or twice. But I warned them and said to them, "Why do you spend the night in front of the wall? If you do so again, I will lay hands on you." From that time on they did not come on the Sabbath.

We see in Nehemiah's example a lone voice that seeks to find ways to resist the market logic of more and more; the drive to shop around the clock that has become such an integral part of the contemporary mall culture and the must-have mentality cultivated by advertisements and the mass media. One senses in this text something of what Abraham Heschel describes as people's inherent inability of leaving behind worldly things - a tendency countered by the Sabbath which he describes as the space in "which [hu]man (sic) avows his/[her](sic) independence of that which is the world's chief idol."16 Albeit by forceful means, there is an attempt in this text to reclaim the Sabbath as, what Heschel has termed, a 'sanctuary in time' - a day in which the true potential of the Sabbath of rest for all can be implemented.

A second text that makes a similar point comes from the story in Exodus 16 of God providing manna to Israel in the wilderness. It is interesting that the rhythm of six days of work and a day of Sabbath rest forms an integral part of this story when the people are commanded to go out six days of the week to find the divine gift of manna, but to rest on the Sabbath day. A central theme in this story is that the manna offered the Israelites just what they needed, no more and no less. In vv 19-20 it says that the Israelites could not store the manna overnight, but how they had to go out each day to find bread for that particular day. Those that tried to store the manna overnight were unhappily surprised in the morning when the manna turned out to be stale. On the Sabbath day, though, the daily rhythm is interrupted when there is no manna to be found (vv 25-27). And yet, no one was left hungry, as for this one special day in the week, God made special provision. When the people gathered manna on the sixth day, they saw that they had gathered a double portion

Woodhead; Grand Rapids, MI: Eerdmans, 2006), 200. Cf. also Jurgen Moltman, 'The Right to Meaningful Work,' in On Human Dignity: Political Theology and Ethics (Great Britain: SCM Press, 1984), 54-55.

16 Heschel, The Sabbath, 29. 
(v. 22), and moreover, this manna could be stored overnight to be used on the day of the Sabbath. ${ }^{17}$

From this fascinating story, one sees how work is considered important, but how human activity is relativized by means of the Sabbath day, interrupting the daily routine and the typical human tendency of more and more. Closely related to the manna that in this text is very much portrayed as the 'food of temperance,' providing just what you need (cf. e.g. the reference in $\mathrm{v} 18$ that the Israelites lacked nothing), that symbolizes a lifestyle according to which the individual's needs are met but where greed, self-centeredness and a seven-day workweek is countered. $^{18}$

Particularly in a context where 'the forces of fragmentation' which are characteristic of the global economy that threatens to affect the dignity of individuals and groups, the notion of the Sabbath serves as a means to resist harmful economic practices by interrupting the daily rhythms of work that are set on profit at all cost. Constituting a vital aspect of what Douglas Meeks has called, 'the practice of the economy of grace,' the Sabbath day is considered to be essential for 'the creation of the commonwealth that mutually assures dignity for all. ${ }^{19}$

\section{Human Dignity and Rest}

Abraham Heschel describes the Sabbath command to rest in the following poetic terms: "In the tempestuous ocean of time and toil there are islands of stillness where $[\mathrm{hu}] \mathrm{man}[\mathrm{s}](\mathrm{sic})$ may enter a harbour and reclaim his/[her](sic) dignity." ${ }^{20}$ Making a profound connection between the call to rest and the individual's inherent self-worth and dignity, Heschel challenges us to ask questions already contemplated in the Decalogue and its commentary in the rest of the biblical traditions, namely, who gets to rest? For instance in both the Exodus and the Deuteronomy version of the Sabbath commandment, it is not only you who is called upon to rest, but also your son and daughter, your male or female slave, the foreigner who resides in your midst, as well as your animals. It is interesting that the Deuteronomy version expands the original list by making explicit reference of your ox or your donkey and by repeating the reference to your male and female slave a second time.

These additions, which reiterate God's special concern for the vulnerable and the needy, aligns with the motivation given in the Deuteronomy version of the Sabbath commandment, when Israel's own experience of suffering under the hand of the cruel slave

17 Aaron Schart notes that especially on the Sabbath day, Israel experienced God's care and its reliance on God. The reason for this is that God is not only providing a day of rest for God's children, but also miraculously ensures that this rest does not occur at the expense of their daily needs, Mose und Israel im Konflict: Eine Redaktionsgeschichtliche Studie zu den Wüstenerzählungen (Göttingen: Vandenhoeck \& Ruprecht, 1990), 123; Erich Zenger furthermore argues that the connection of God's gift of food and the Sabbath makes a theological claim of God as the provider of vitality. Thus, both food and weekly rest are needed to rejuvenate the body, Das Buch Exodus (GeistS 7; Düsseldorf: Patmos-Verlag, 1987), 166-167.

18 Göran Larsson describes the manna as the food of temperance - it is exactly what a human needs, neither more nor less, Bound for Freedom: The Book of Exodus in Jewish and Christian Traditions (Peabody, Mass.: Hendrickson, 1999), 117. We see this in the reference to the manna being described as the, "bread for satisfaction' (v. 8) or 'your fill of bread' to eat (v. 12). Thus, the manna provides exactly what people need no more and no less. Cf. also the repeated reference that the manna should be picked up 'according to each person's needs' (in vv. 16, 18; the same expression with in v. 21).

19 According to Meeks, the Torah household rules of the economy of grace comprise the following: (1) Practice hospitality (2) Practice the tithe (3) Do not harvest until the edge of the field; leave gleanings for the poor (4) Do not charge interest to the poor (5) Practice the Sabbath, 'The Economy of Grace,' 203.

20 Heschel, The Sabbath, 29. 
masters in Egypt becomes the basis for prohibiting the maltreatment of those who find themselves working for you. This rationale for making rest possible for those who are dependent on you very much indicates that rest is considered to be a vital human need.

However, all too often when it comes to people living in dire need, rest or leisure is not a given. Affecting especially women who live in impoverished conditions, many women in rural areas in the developing world spend hours (in some instances up to seven hours) each day collecting firewood and water, in addition to working the fields and cultivating food. ${ }^{21}$ Rest is thus for many a luxury they do not know, denoting once more just on how many levels poverty dehumanizes those in its claws. From the Sabbath commandment it is evident that the need to rest and express oneself in other ways than in work, is a vital aspect of human worth and essential for a person's sanity and overall quality of life.

Actually, in the case of Israel's experience in Egypt, Patrick Miller points out that it is "the Pharaoh's exploitation of human life and human work that triggers God's gift of the Sabbath." ${ }^{22}$ In this regard, one sees in this text how the Deuteronomy motivation for the Sabbath commandment forges a connection between my experience and the experience of the other who is intrinsically connected to me. It is the memory of how it felt to work all the time under a cruel tyrant that ought to be responsible for the fact that I myself do not become a tyrant to others.

It is further significant that the care for the neighbour that will be the topic of the second part of the Decalogue, is already introduced in the Sabbath commandment in the charge to let your servants rest. As Patrick Miller notes, the very first reference to care for the neighbour in the Deuteronomy version is to be found in the face of one's servant, as well as in the face of the stranger or the foreigner or the resident alien in your midst. ${ }^{23}$

Also in Exodus 21-23 that serves as a type of exposition of the Decalogue, one finds how the significance of the Sabbath rest is extended to include other marginal groups in the community. In Exod 23:9-13, just before the Sabbath commandment, the Sabbath principle finds expression in the Year of Release according to which the seventh year is dedicated to the poor of your people so that they may eat, as well as to the animals that are to eat what is not taken by the poor. Exodus 23, as well as texts such as Lev 25:1-7 and Deut 15:1-11 that introduce the notion of a Sabbath (every seventh year) and Jubilee Year (every 50 years) have in common that they make provision for the wellbeing of the marginalized groups in society, as well as for the land to rest too - the land that like humans and animals, could also be overworked and abused; hence losing its productive capacity. It seems as if the theological principle at the heart of the Sabbath commandment to ensure rest for your animals, your slaves and the foreigners in your midst, is extended to cultivate economic practices that ensure the possibility of life for those at risk, so building in a drive for justice and compassion into Israel's social structures. ${ }^{24}$

21 Alaka Malwade Basu, Women, Poverty and Demographic Change (ed. Brigida Garcia; Oxford: Oxford University Press, 2000), 24-25. Cf. also Nancy Bonvillain, Women and Men: Cultural Constructs of Gender, $4^{\text {th }}$ edition (Upper Saddle River, NJ: Prentice Hall, 2007), 170-182.

22 Miller, The Ten Commandments, 130.

23 Miller, The Ten Commandments, 127-128. Van Wijk-Bos notes that the fact that Israel were once 'strangers in the land of Egypt' forms "a strong part of their identity, and through the recall of this identity, the covenant community has access to past experience as if it were their own. Much of the history of ancient Israel as a settled people involved subsequent suffering and oppression, so that ongoing experience provided a ready access to memory. It is remarkable that the appeal to personal experience of past suffering from hostile behavior of host to stranger became a motivation not for revenge but for avoiding the same behavior," Making Wise the Simple, 30.

24 Miller, The Ten Commandments, 135-148; Van Wijk-Bos, Making Wise the Simple, 183. 
The texts outlining the Sabbath and Jubilee may likely have been unrealistic, farfetched and probably never worked like this in practice. Moreover, as Esias Meyer has rightly shown, texts such as Leviticus 25 in reality reflected the interests of the elite returnees from exile in Babylon, thus only championing justice for a few and not including justice for the people of the land or the children, women and slaves in the community. ${ }^{25}$

And yet the notion of the Sabbath as a gracious gift from God according to which all are granted the chance to be rested, refreshed, and restored offers us as Abraham Heschel has argued, a glimpse of the world to come that ought to challenge us to carry over something of the Sabbath spirit into the rest of the work week. So the Sabbath memory of being set free finds true expression in the constant re-enactment of Sabbath principles in daily life in Miller's words 'to keep human life human. ${ }^{26}$ Moreover, we who are aware of the ostracised and the silenced voices in the text have a special obligation to ensure that justice in today's context truly is extended to all.

\section{Conclusion}

When utilizing the Sabbath commandment in a context of human dignity, it is important to see that the focus of this commandment ought to extend beyond a legalistic understanding of the Sabbath that places a heavy burden on the believer. Moreover, contrary to the way the Sabbath is filled in these days, the Sabbath is also not just a day like any other day; a concept void of any theological significance. Rather as we have seen in this paper, the Sabbath serves as a constant reminder of how the world can and should be. ${ }^{27}$

In this regard, it is significant to see what central role the Sabbath plays in Russel Botman's contribution to the volume, God and Human Dignity. In his essay, Botman uses the analogy of a household (oikos) to express the notion of how humans live together in the world. He writes:

Oikos is given in creation and unfolds in Israel. God's 'house rules' are given to all humanity, and also, in a special way to Israel. Their aim is to sustain relationships and true humanity within the household. Above all else the house rules are meant to protect the humanity and the livelihood for the weakest and poorest in the oikos. For this reason the concept of Sabbath becomes an important part of oikos. It refers to the restored order of the household of the whole creation which permits all creatures to live and dwell in peace. $^{28}$

These house rules affect everything. For instance, in his essay on human dignity and the economy, Douglas Meeks writes how within this common oikos, "God creates homemakers, that is, 'economists' or 'disciples.' The mandate of this economy is to bring

25 Esias E Meyer notes that 'everybody' in the context of Leviticus probably means every male with a claim to land. The inclination underlying Leviticus 25 to protect this small elite of landowning people probably does not denote 'everyone' in a modern sense, The Jubilee in Leviticus 25: A Theological Ethical Interpretation from a South African Perspective (Münster: LitVerlag, 2005), 262-264, 282. Particularly in light of South Africa's complex history of biblical interpretation according to which the Bible was used to justify apartheid as well as justice for a few privileged few, Meyer is right that as critical biblical interpreters we have an obligation to read these texts with a critical eye.

26 Miller, The Ten Commandments, 149.

27 Abraham Heschel writes that "the Sabbath is the counterpoint of living; the melody sustained throughout all agitations and vicissitudes which menace our conscience; our awareness of God's presence in the world," The Sabbath, 88.

28 H Russel Botman, "Covenantal Anthropology: Integrating Three Contemporary Discourses of Human Dignity," in God and Human Dignity (eds. R Kendall Soulen \& Linda Woodhead; Grand Rapids, MI: Eerdmans, 2006), 81. 
the creation into household relations that serve life rather than death." ${ }^{29}$ Viewed in this fashion, the economy may look very different, more human. Meeks proposes the following:

The humanization of economy thus demands that we once again recognize that economy is embedded in community and exists for the sake of the enhancement of community.

The viability of human community is a greater value than free trade and the increase of wealth through financial markets. ${ }^{30}$

Part of our tasks as theologians is to continue to think about the role we can play in this broader conversation that intersects fields of theology, economy and politics. I would suggest that as theologians we have the privilege, as well as the obligation, to draw on our rich theological resources as also evident in the contemplation of the Sabbath commandment in a context of human dignity, to hold the world accountable when it comes to the way economical and societal structures impact the lives of the last and the least of these.

29 Meeks, 'The Economy of Grace,' 200.

30 Meeks, 'The Economy of Grace,' 209. 